\title{
Proteinuria, CTCAE 5.0
}

National Cancer Institute

\section{Source}

National Cancer Institute. Proteinuria, CT CAE 5.0. NCI Thesaurus. Code C146758.

A disorder characterized by laboratory test results that indicate the presence of excessive protein in the urine. It is predominantly albumin, but also globulin. 